\title{
OPTIMALISASI WIRAUSAHA SALAH SATU FAKTOR PENDUKUNG TERCIPTANYA KEMANDIRIAN EKONOMI DAERAH
}

\author{
Eko Meiningsih Susilowati ${ }^{1)}$ \\ Endah Nawangsasi ${ }^{2)}$ \\ STIE Adi Unggul Bhirawa Surakarta \\ susilowatieko7@gmail.com
}

\begin{abstract}
ABSTRAKSI
Wirausaha merupakan suatu yang sangat penting. Dalam wirausaha ada aktivitas atau kegiatan yang diharapkan dapat meningkatkan pendapatan. Meskipun banyak persaingan dalam usaha haruslah tetap berusaha untuk dapat bertahan dan berkembang. Agar pendapatan dapat meningkat hal yang dapat dilakukan salah satunya adalah mengoptimalkan wirausaha yang baik dan benar. Cara yang dapat dilakuakan dengan membuat skala prioritas kegiatan apa dulu yang harus dilakukan. dan apabila diperlukan dapat mengevaluasinya. Kegiatan pelaksanaan pengabdian ini dilakukan dalam bentuk pelatihan dan pendampingan dalam mengoptimalkan wirausaha menuju kemandirian ekonomi. Pelaksanaan kegiataan ini dilaksanakan pada tanggal 10 Agustus 2018 di Dusun karagpandan Desa Karangpandan Kabupaten Karanganyar. Metode pelatihan menggunakan metode ceramah dan penyampaian materi, diskusi dan tanya jawab, dan konsultasi berkelanjutan. Hasil dari kegiatan ini adalah para peserta memperoleh bekal ilmu tentang optimalisasi wirausaha untuk meningkatkan pendapatan dengan tujuan agar kemandirian ekonomi dapat terwujud.
\end{abstract}

Kata kunci: wirausaha, kemandirian ekonomi

\section{PENDAHULUAN}

Kabupaten Karanganyar mempunyai wilayah yang luas. Wilayah tersebut merupakan wilayah yang produktif. Disamping sektor pertanian yang baik di wilayah tersebut juga mempunyai banyak tempattempat pariwisata. Banyaknya tempat-tempat wisata bisa membuka peluang bagi masyarakat disana untuk melakukan suatu usaha, terutama bagi para ibu rumah tangga. Dimana para ibu rumah tangga dapat membuat produk makanan ringan misalnya untuk menambah penghasilan yang sudah ada dan dapat meningkatkan pendapatan per kapita di daerah tersebut. Pendapatan per kapita naik berarti pendapatan daerah naik sehingga ekonomi masyarakat bisa menjadi lebih baik. Mengapa penting dibutuhkan banyak wirausaha? karena peran yang bisa diberikan oleh para wirausaha besar seperti mengurangi jumlah pengangguran, mengurangi kemiskinan, meningkatkan daya beli masyarakat, dan dapat menciptakan lapangan usaha baru yang semua itu dapat meningkatkan pertumbuhan ekonomi.

Pilihan menjadi seorang wirausaha sendiri disebabkan salah satunya adalah karena adanya keyakinan yang kuat secara individual wirausaha itu merupakan cara untuk melakukan perubahan dalam kualitas hidup baik secara individual maupun dalam bermasyarakat. Kualitas yang diinginkan adalah menjadi lebih sejahtera dan lebih makmur dari segi ekonomi. Penelitian yang dilakukan oleh Frinces (2010) dapat disimpulkan bahwa profesi sebagai wirausaha adalah sebuah pilihan untuk hidup dan sebagai profesi yang terhormat yang harus direncanakan secara baik dan matang. Wirausaha adalah jalan yang dipilih dan diyakini. Pada kenyataan dan fakta yang ada wirausaha mempunyai peran yang besar dalam meningkatkan kualitas hidup. Wirausaha juga merupakan salah satu faktor yang menentukan masyarakat dan negara menjadi makmur. Penelitian yang dilakukan oleh Suprapti dan Riyanto disimpulkan bahwa ada faktor-faktor yang mempengaruhi perempuan dalam aktivitas kewirausahaan yaitu faktor ekonomi, faktor teknologi, faktor sosial demografi, faktor persepsi dan faktor kurang percaya diri. 


\section{METODE ATAU APLIKASI}

\section{Pemecahan Masalah}

Mengoptimalkan wirausaha di suatu daerah merupakan suatu yang sangat penting. Hal ini dikarenakan dengan adanya banyak wirausaha yang ada di daerah tersebut maka pendapatan akan meningkat dengan begitu akan meningkatkan pula pendapatan asli daerah. Dengan meningkatnya pendapatan asli daerah diharapkan masyarakat dapat mandiri dalam segi ekonmi, sehingga kemakmuran hidup dapat terwujud. Untuk mewujudkan kemandirian ekonomi dengan mengoptimalisasikan wirausaha harus dilakukan dengan kerja keras dan sungguh-sungguh. Dengan wirausaha kita akan melakukan kegiatan atau aktivitas sesuai dengan keahlian dan ketrampilan yang dimiliki. Melakukan wirausaha bukan merupakan suatu yang mudah dan dapat dikerjakan begitu saja oleh semua orang. Seperti diketahui bahwa suatu usaha pastilah mempunyai banyak pesaing. Dengan banyaknya pesaing tersebut membuat kita harus berpikir bagaimana bisa menang dalam persaingan tersebut, atau paling tidak bisa bertahan dan berkembang. Melalui optimalisasi wirausaha kita akan belajar cara mengambil melakukan kegiatan sesuai kondisi keahlian dan ketrampilan masing-masing. Kita dapat memprioritaskan kegiatan apa yang akan dilakukan, sehingga tujuan yang diharapkan dapat tercapai. Keahlian dan ketrampilan penting karena setiap orang mempunyai kemampuan yang berbeda. Kemampuan tersebut sangat tergantung pada cara serta kesungguhan yang dilakukan. Melalui optimalisasi wirausaha yang baik, maka pendapatan akan meningkat, sehingga akan menciptakan kemandirian ekonomi.

\section{Realisasi Pemecahan Masalah}

1. Pembinaan dan Pengawasan

a. Pemberian pelatihan tentang bagaimana cara mengoptimalkan usaha yang mereka jalani agar dapat segera menciptakan kemandirian ekonomi di wilayah mereka.

b. Memberikan pelatihan tentang bagaimana menentukan skala prioritas untuk mewujudkan kemandirian mereka secara ekonomi.

\section{Pola Pendampingan}

Memberikan pendampingan dan cara-cara dalam mengoptimalkan usaha yang mereka jalani dan penentuan skala prioritas.

\section{Khalayak Sasaran}

Khalayak sasaran dalam bentuk pelatihan yang diikuti oleh para ibu di lingkungan Dusun Karangpandan Desa Karangpandan Kabupaten Karangnganyar.

\section{Metode Pelaksanaan Pengabdian}

Kegiatan pelaksanaan pengabdian ini dalam bentuk pelatihan dan pendampingan dalam rangka optimalisasi wirausaha untuk mendukung terciptanya kemandirian ekonomi. Pelaksanaan kegiataan ini dilaksanakan pada tanggal 10 Agustus 2018 di Dusun Karangpandan Desa Karangpandan Kabupaten Karangnganyar, pada jam 14.00 wib-selesai. Metode pelatihan yang digunakan yaitu:

1. Metode ceramah dan penyampaian materi oleh tim pengabdian kepada masyarakat STIE-AUB Surakarta. Penyampaian ini dengan memberikan materi tentang bagaimana cara mengoptimalkan para wirausaha untuk mendukung terciptanya kemandirian ekonomi.

2. Diskusi dan tanya jawab. Dalam metode ini tim pengabdian STIE-AUB Surakarta memberikan kesempatan kepada peserta untuk menanyakan mengenai hal-hal belum mereka dipahami mengenai materi yang telah disampaikan.

3. Konsultasi berkelanjutan kepada tim pengabdian STIE-AUB Surakarta jika menemui kesulitan. Persoalan yang banyak ditanyakan adalah bagaimana cara mengoptimalkan usaha mereka agar kemandirian ekonomi di daerah mereka segera tercapai. 


\section{HASIL DAN PEMBAHASAN}

Kegiatan pengabdian kepada masyarakat ini adalah pelatihan dan pendampingan tentang mengoptimalkan wirausaha dalam rangka menciptakan kemandirian ekonomi yang dilaksanakan pada tanggal 10 Agustus 2018. Hasil dari pelatihan ini adalah para peserta memperoleh bekal ilmu tentang bagaimana cara mengoptimalkan usaha yang mereka miliki dalam rangka mewujudkan kemandirian ekonomi. Selain itu para peserta juga memperoleh pengetahuan tentang bagaimana menentukan skala prioritas yang akan dilalui.

Hasil dari pelatihan ini adalah para peserta memperoleh bekal ilmu tentang bagaimana mengoptimalkan usaha untuk kemandirian ekonomi di wilayah mereka. Selain itu para peserta juga memperoleh pengetahuan tentang bagaimana menentukan skala prioritas untuk segera mewujudkan kemandirian ekonomi. Tim pengabdian akan melakukan pendampingan dan memberikan masukan apabila mereka menemui kesulitan dalam mengelola usaha mereka.

\section{KESIMPULAN DAN SARAN}

Wirausaha merupakan keterampilan yang dimiliki oleh seseorang dan diperlukan dalam masyarakat untuk proses peningkatan pendapatan daerah dan untuk menciptakan kemandirian ekonomi daerah. Salah satunya bagi para ibu rumah tangga. Melalui wirausaha yang baik dan benar, pendapatan yang diperoleh keluarga diharapkan dapat meningkat. Dengan begitu pendapatan daerahpun juga akan meningkat sehingga kemandirian ekonomi dapat terwujud. Harapan yang dapat diambil manfaatnya melalui kegiatan ini yaitu betapa pentingnya mengoptimalisasikan wirausaha untuk menaikkan pendapatan dan menciptakan kemandirian ekonomi di wilayah masing-masing. Saran yang bisa diberikan dalam kegiatan ini adalah peserta diharapkan dapat melakukan wirausaha dan dilakukan dengan sungguh-sungguh sehingga hasil pendapatannya bisa maksimal dan selalu membuat daftar skala prioritas dan sesuai dengan rencana sebelumnya.

\section{REFERENSI}

Frinces, Z. Heflin. 2010. Pentingnya Profesi Wirausaha Di Indonesia. Jurnal Ekonomi \& Pendidikan. Vol. 7, No. 1: 34-57.

Suprapti dan Riyanto. Key sukses faktor intrepreneur activity berdasar gender dalam pengembangan kewirausahaan. Jurnal Serat Acitya. Untag Semarang. 